Research paper

\title{
Evaluating the groundwater potential of coastal aquifer using geoelectrical resistivity survey and porosity estimation: A case in Ota, SW Nigeria
} \author{
Cherish E. Thompson ${ }^{\mathrm{e}}$, Francis S. Ajayi ${ }^{\mathrm{b}}$, Osagie A. Ekhaguere ${ }^{\mathrm{f}}$ \\ a Applied Geophysics Unit, College of Science and Tech, Covenant University, Nigeria \\ ${ }^{\mathrm{b}}$ Department of Archeology, King Saul University, Saudi Arabia

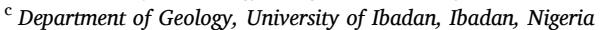 \\ ${ }^{\mathrm{d}}$ Boone Pickens School of Geology, Oklahoma State University, Stillwater, OK, USA \\ e Applied Geophysics Unit, Department of Physics, University of Calabar, Calabar, Nigeria \\ ${ }^{\mathrm{f}}$ Department of Physics, Federal University of Agriculture, Abeokuta, Nigeria
}

Kehinde D. Oyeyemi ${ }^{\text {a,* }}$, Ahzegbobor P. Aizebeokhai ${ }^{a}$, Mohamed Metwaly ${ }^{\mathrm{b}}$, Michael A. Oladunjoye ${ }^{c}$, BabaMayowa A. Bayo-Solarin ${ }^{\mathrm{a}}$, Oluseun A. Sanuade ${ }^{\mathrm{d}}$,

\section{A R T I C L E I N F O}

\section{Keywords:}

Subsurface characterization

Groundwater exploration

Aquifer porosity

Hydrogeophysics

Ota

Nigeria

\begin{abstract}
A B S T R A C T
Geoelectrical resistivity sounding surveys was carried out at two locations (A and B) in the new CanaanCity residential estate of Canaan land Ota, Ogun state in order to locate possible targets for groundwater explorations. A total of twelve (12) vertical electrical soundings were conducted using the Schlumberger array configuration. The interpretations of the VES curves revealed five to six geoelectrical layers at location A which comprises VES1-7. The geoelectric units consist of the topsoil, sandy clay, lateritic clay, confining bed (clayey sand), and main aquifer (sand). The top of the aquifer in this part of the study area is between $40 \mathrm{~m}$ and $83.5 \mathrm{~m}$. Likewise, a total of five to seven layers of geoelectrical units were delineated at the location B portion of the study site (VES 8-12) similar to location A with an addition of the shale unit that was interpreted to be that of the Akimbo Formation of the Dahomey Basin. The depth to the top of the productive aquifer within location $\mathrm{B}$ is in the range of 40-112.4 m. The delineated basal shale layer is impermeable, serving as the base seal rock for the confined aquifer system. The estimated porosity values range from $28 \%$ to $74 \%$, indicating that the highly porous aquifer system in the area is the coastal plain sands mixed with the alluvium sand of the Benin Formation of Dahomey Basin. The study revealed the complexity of the productive aquifer system in the area and its undulating topography.
\end{abstract}

\section{Introduction}

The risk of drilling less productive or unproductive borehole for groundwater resources through highly expensive drilling method is avoidable by conducting cost-effective geophysical investigations. The information that could be obtained from geophysical studies includes the thickness and the depth to the groundwater reservoir (aquifer). Other important derivative information is the geohydraulic parameters of the subsurface aquifer which include aquifer hydraulic conductivity, porosity and permeability (Yadav, 1995; Soupios et al., 2007; Chandra et al., 2008; Uyanık, 2011; Aizebeokhai and Oyeyemi, 2015; Aizebeokhai et al., 2016a, 2016b; Aizebeokhai et al., 2017a, 2017b; Aizebeokhai and Oyeyemi, 2018, 2018b; Aizebeokhai et al., 2018a, 2018b;
Aizebeokhai et al., 2019; Umi Maslinda and Nordiana, 2018). The geoelectrical sounding or vertical electrical sounding (VES) technique measures the distribution of electrical resistivity in the subsurface. This technique is widely used for aquifer delineation as it can penetrate deeper into the subsurface (Oyeyemi et al., 2019). In addition, the technique of VES is quite non-destructive and lower cost-effective to locate aquifer compared to the direct borehole drilling.

Subsurface aquifers comprise of porous rocks that are capable of storing water for household and industrial use. The productivity of an aquifer unit depends on factors such as its depth, thickness, resistivity, and petrophysical properties like fluid saturation, mineral content, porosity, permeability, and groundwater contamination (Meju et al., 1999; Karlık and Kaya, 2001; Kaya et al., 2007; Balkaya et al., 2009;

\footnotetext{
* Corresponding author.

E-mail addresses: kehinde.oyeyemi@covenantuniversity.edu.ng, kehinde.oyeyemi@covenanatuniversity.edu.ng (K.D. Oyeyemi).
} 


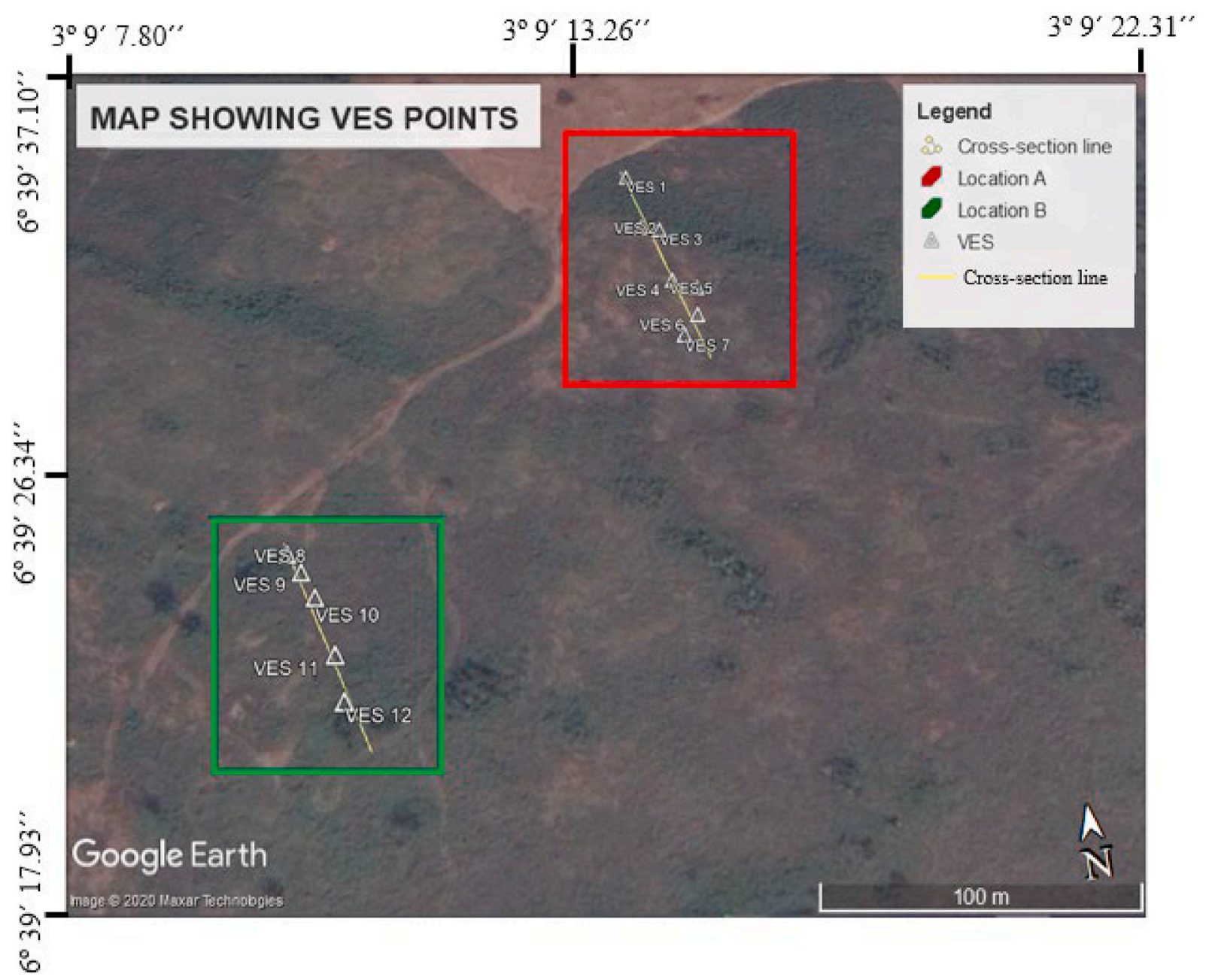

Fig. 1. Location of study area showing the VES points. 


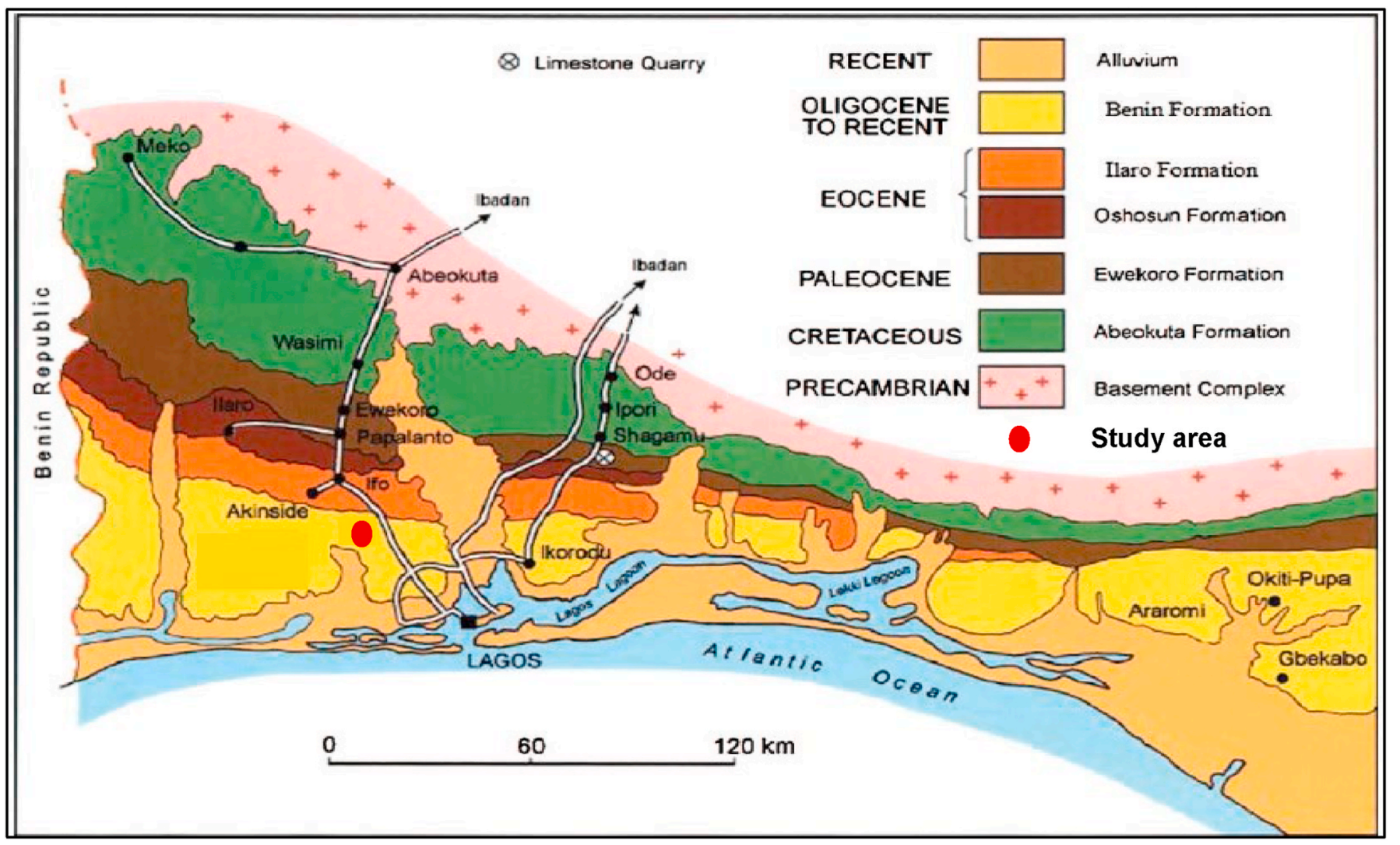

Fig. 2. Generalized geological map of Eastern Dahomey Basin (modified after Gebhardt et al., 2010).

Fatoba et al., 2017; Olaojo et al., 2018; Oyeyemi et al., 2018a; 2018b, 2018c). The complexity of subsurface geology necessitates the applications of geophysical methods to avoid drilling an unproductive borehole during groundwater exploration, development, and management. The efficient geophysical investigation will enhance the understanding of the subsurface characteristics that will help to locate aquifer with high groundwater yield with higher accuracy; develop and manage the available groundwater for the greater good. This research focuses on the use of the geoelectrical resistivity method to locate the productive subsurface aquifer and estimate its petrophysical properties with a view to evaluating its potential for sustainable groundwater exploration, development, and management.

\subsection{Study area and geological setting}

The selected study area for this project is the Canaan-City residential estate within Ota, Ado - Odo/Ota L.G.A., Ogun state in southwestern Nigeria (Fig. 1). The study area is located within the longitude $3^{\circ} 9^{\prime}$ $7.80^{\prime \prime} \mathrm{E}$ to $3^{\circ} 9^{\prime} 22.31^{\prime \prime} \mathrm{E}$, and latitude $6^{\circ} 39^{\prime} 17.93^{\prime \prime} \mathrm{N}$ to $6^{\circ} 39^{\prime} 37.10^{\prime \prime} \mathrm{N}$. The regional geology of this area is that of the eastern Dahomey basin, where the regional strike of the sedimentary deposit is in E-W direction (Fig. 2). The basin is characterized by six lithological units that are of Late Cretaceous to Early Tertiary in age (Jones and Hockey, 1964;
Olabode, 2006; Omatsola and Adegoke, 1981). They are Abeokuta group (comprising Araromi, Afowo and Ise Formations), Ewekoro Formation, Akinbo Formation, Oshosun, Ilaro, and Benin Formation in the descending order of their geologic age. These lithostratigraphic units have been discussed extensively by various authors (e.g., Ako et al., 1980; Okosun, 1990; Elueze and Nton, 2004). The Abeokuta Formation is Cretaceous in age and composed of continental pebbly sands with intercalations of silt, mudstone, shale/clay, and thin limestone unit as a result of marine transgression. The Palaeocene Ewekoro formation is a limestone unit that is of shallow marine facies. Akinbo Formation is a shale dominated unit of Late Paleocene to Early Eocene. Oshosun Formation is a shale unit of Eocene age, while Ilaro Formation is a sequence of coarse sand units of the deltaic, estuary, and continental environments. Overlying the Ilaro Formation is the Oligocene to Recent Benin Formation that is a predominantly sand unit. The hydrogeological studies of the area have revealed that the coastal plain sands and the alluvium unit of the Benin Formation serve as the subsurface aquifer units.

\section{Methodology}

Twelve VES were conducted at different points within the CanaanCity Estate using the Schlumberger electrode configuration. The

Table 1

The suggested values for tortuosity and cementation factor in Archie's relation (Keller, 1987; Umi Maslinda and Nordiana, 2018).

\begin{tabular}{|c|c|c|}
\hline Description of rock & a & $\mathrm{m}$ \\
\hline Weak cemented detrital rocks, such as sand, sandstone and some limestone with a porosity range from 0.25 to 0.45 , usually tertiary in age & 0.88 & 1.37 \\
\hline Moderately well-cemented sedimentary rocks, including sandstone and limestone with a porosity range of 0.18 and 0.35 , usually Mesozoic age & 0.62 & 1.72 \\
\hline Well-cemented sedimentary rocks with a porosity range from 0.05 to 0.25 , usually Paleozoic in age & 0.62 & 1.95 \\
\hline $\begin{array}{l}\text { High porous volcanic rocks, such as tuff, aa, pahoehoe with porosity range } \\
0.2-0.8\end{array}$ & 3.5 & 1.44 \\
\hline Rocks with less than 0.04 porosity, including igneous rocks and metamorphosed sedimentary rocks & 1.4 & 1.58 \\
\hline
\end{tabular}



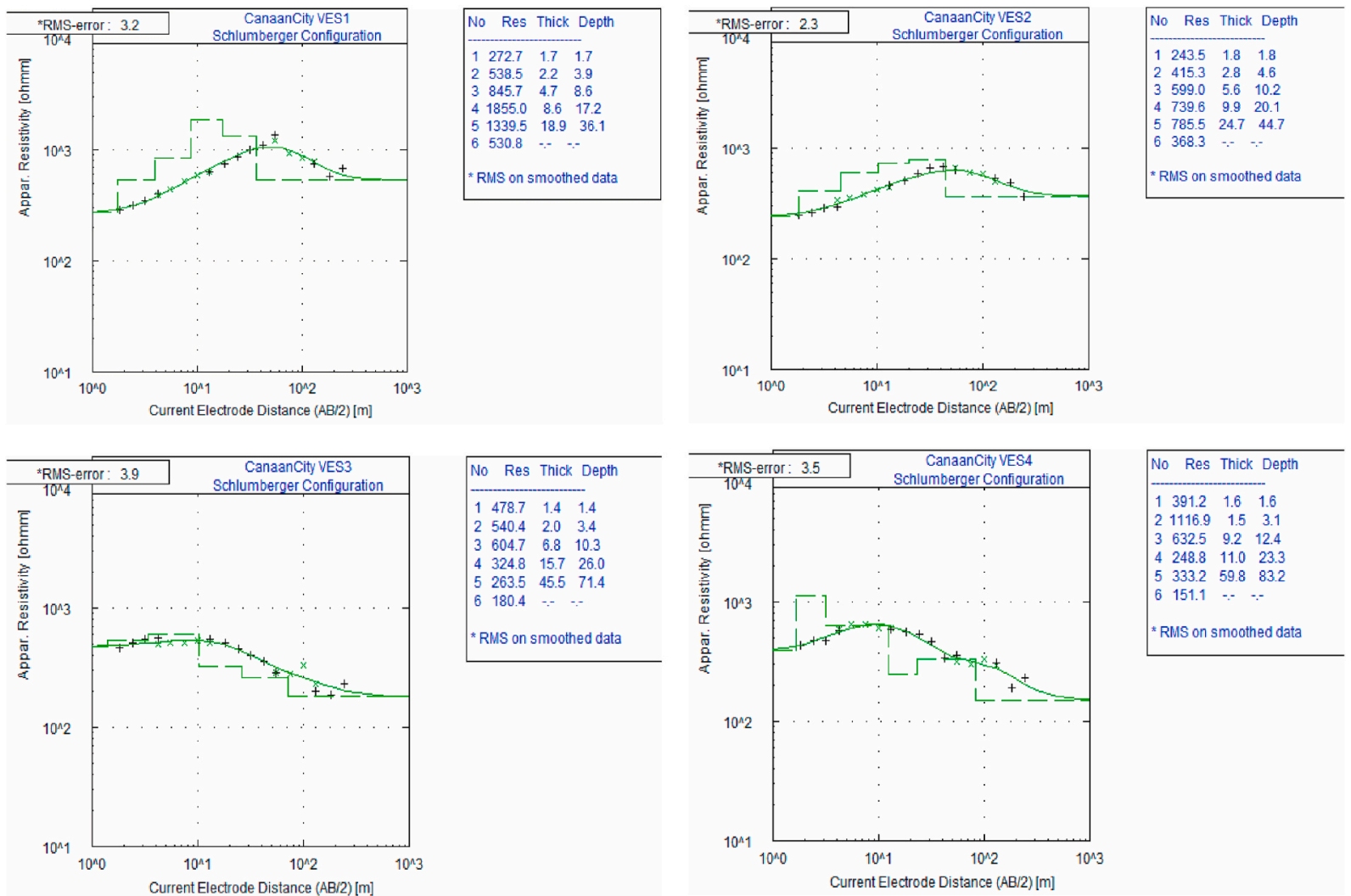

Fig. 3. Representative inverse resistivity models of VES 1-4.

maximum spacing for the current electrodes $(A B / 2)$ used in this study is $240 \mathrm{~m}$. The apparent resistivity of the traverses was measured using the ABEM (SAS 1000/4000 series) resistivity meter, which was set to take the readings at a minimum of 3 cycles and a maximum of 4 cycles (i.e., it will obtain the mean of 3 or 4 measurements). The spacing of $A B / 2$ started at $1.0 \mathrm{~m}$ and increased while potential spacing $(\mathrm{MN} / 2)$ was fixed at a point until $\mathrm{AB} / 2$ became large that an increase in potential became necessary. The measured apparent resistivity values were plotted against their respective current electrode spacing $(\mathrm{AB} / 2)$ on a bi-log graph and were presented as sounding curves. Quantitative interpretations of the VES curves were carried out using partial curve matching technique and computer-aided 1-D forward modeling using WinResist 1.0 software.

Aquifer porosity $(\phi)$ was estimated using the Achie's relation (equation (1)), and this is based on the fact that the electrical resistivity of any geomaterial affects its porosity (Oyeyemi and Olofinnade, 2016; Oyeyemi et al., 2018b).

$\rho_{f}=\rho_{w} a \phi^{-m} S^{-2}$

where $\rho_{f}$ and $\rho_{w}$ are the resistivities of aquifer formation and pore water, respectively. The parameters ' $a$ ', ' $m$ ', and ' $\mathrm{s}$ ' are the tortuosity, cementation factor, and water saturation, respectively. The resistivity of aquifer formation was obtained from the forward model resistivity results of the VES. The conductivity of the water in the formation, measured using conductivity meter, was inverted to obtain the resistivity of the water within the aquifer unit. The values of the tortuosity and cementation factor are dependent on the lithological classification, the extent of consolidation, and the geological age of the formation (Keller, 1987). The aquifer system in the area is said to be that of the coastal plain sands and Tertiary alluvium deposits of Benin Formation, so "a" and " $\mathrm{m}$ " are chosen to be 0.88 and 1.37 respectively (Table 1 ). The aquifer system is also assumed to be fully saturated with water $(S=1)$. The petrophysical parameter was estimated for the aquifer unit, and maps presenting the distributions of all the aquifer parameters in the study area were equally generated.

\section{Results and discussion}

The area of study is divided into location A and location B with about $100 \mathrm{~m}$ spacing, as shown in the base map (Fig. 1). The interpretation of the subsurface layers at these two locations were based on the variations of the electrical resistivity values and the information from the local geology of the study area. VESs 1-7 were conducted in location A, and the interpretation of the sounding data revealed five to six geoelectrical layers (Figs. 3 and 4). The first layer is the topsoil, having a resistivity range of 243.5-664.7 $\Omega \mathrm{m}$, with a thickness range of 1.4-2.1 $\mathrm{m}$. The high resistivity values in the topsoil may be as a result of a high compaction rate due to reworking activities in the study site or could be due to the dryness of the topsoil that probably causes high evaporation rate. The second layer with an inverse model resistivity range of 415.3-1116.9 $\Omega m$ and the thickness range of $2.0-12.6 \mathrm{~m}$ is interpreted to be a sandy clay unit. The third and fourth delineated layers with resistivity range of 171.2-1855.0 $\Omega \mathrm{m}$ and thickness up to $53.9 \mathrm{~m}$ are interpreted to be lateritic clay. The high resistivity values of the lateritic clay may be due to the high compaction rate within this layer. The fifth layer is the confining bed, which is also a clayey sand layer with a resistivity range of 259.7-5139.9 $\Omega \mathrm{m}$ and thickness range 5.7-56.8 $\mathrm{m}$. The sixth layer with a resistivity range of $151.1-530.3 \Omega \mathrm{m}$ is interpreted to be the main aquifer unit, that is, a coarse sand layer. The average depth to the top of the main aquifer within this part of the CanaanCity estate is averagely between $76.4 \mathrm{~m}$.

Location B has VES 8-12, as presented in Fig. 1, and the interpretation of the sounding data revealed six to seven geoelectrical layers (Figs. 4 and 5). The first layer is the topsoil, with a model resistivity values ranging from 27.0 to $258.1 \Omega m$, with a thickness range of $0.7-3.6$ $m$. The second layer is interpreted to be a sandy clay unit with an inverse 

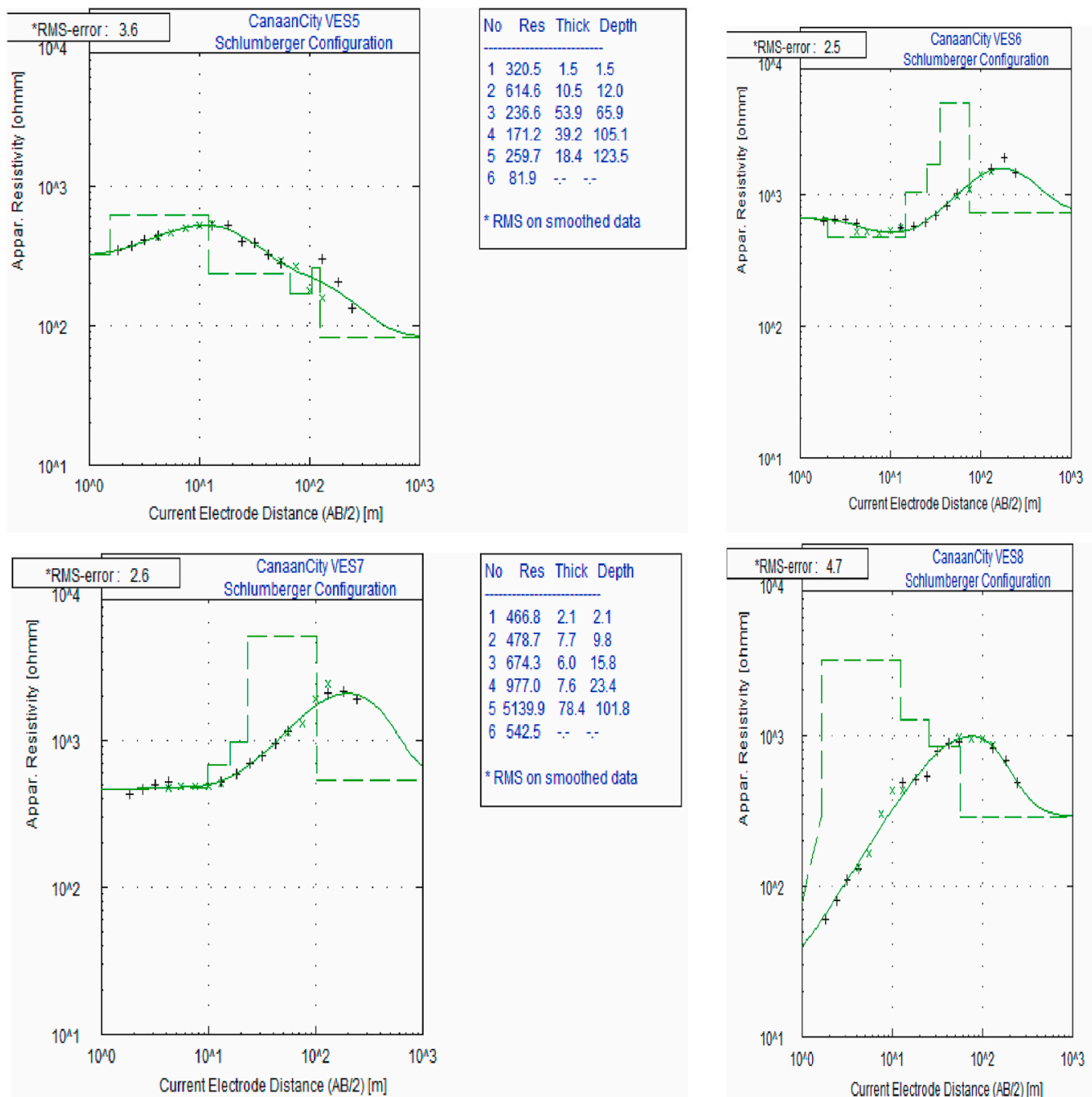
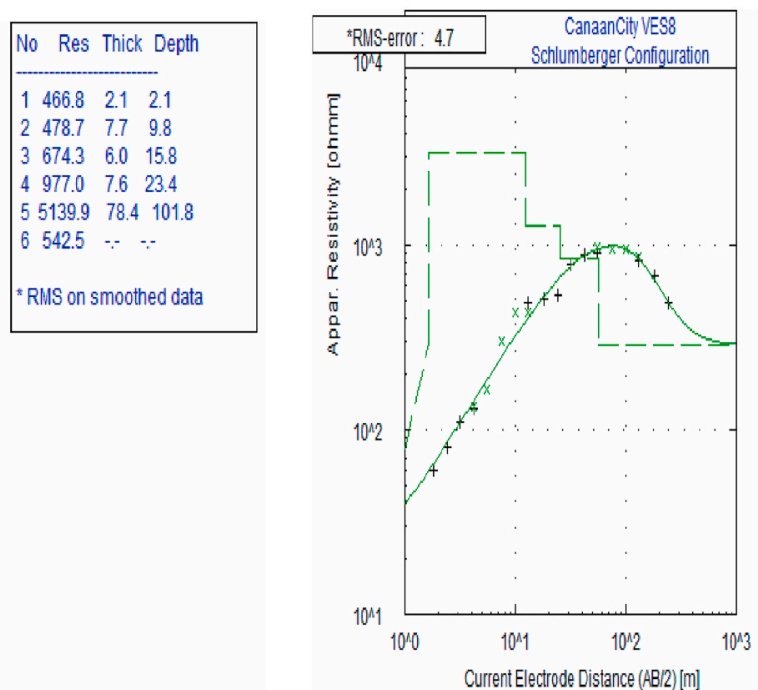

No Res Thick Dept

$\begin{array}{llll}1 & 27.0 & 0.7 & 0.7\end{array}$

$\begin{array}{llll}2 & 2963 & 1.0 & 1.7\end{array}$

$33155.010 .7 \quad 12.4$

41280.413 .125 .5

$5853.130 .5 \quad 56.0$

$6287.8 \div-\because$

RUV on smoothed data

Fig. 4. Representative inverse resistivity models of VES 5-8. 


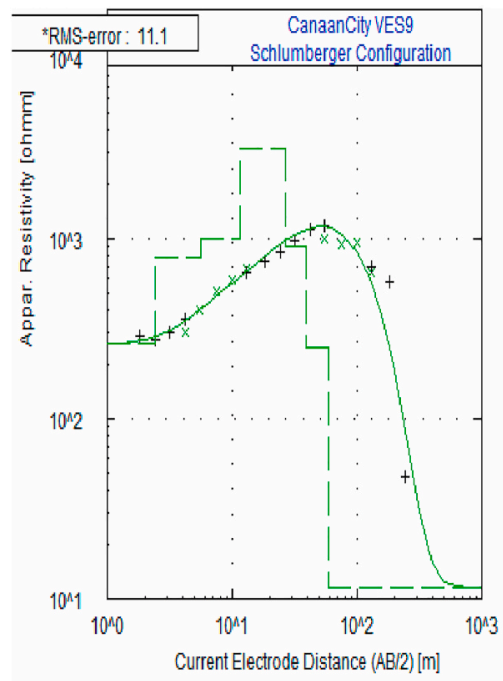

\begin{tabular}{|lllll|}
\hline No & Res & Thick Depth \\
\hline 1 & 258.1 & 2.4 & 2.4 \\
2 & 783.5 & 3.2 & 5.6 \\
3 & 991.6 & 6.0 & 11.6 \\
4 & 3180.4 & 15.2 & 26.7 \\
5 & 918.0 & 12.6 & 39.4 \\
6 & 250.2 & 20.3 & 59.7 \\
7 & 11.4 & -- & -- \\
* & & \\
* & \\
\hline
\end{tabular}
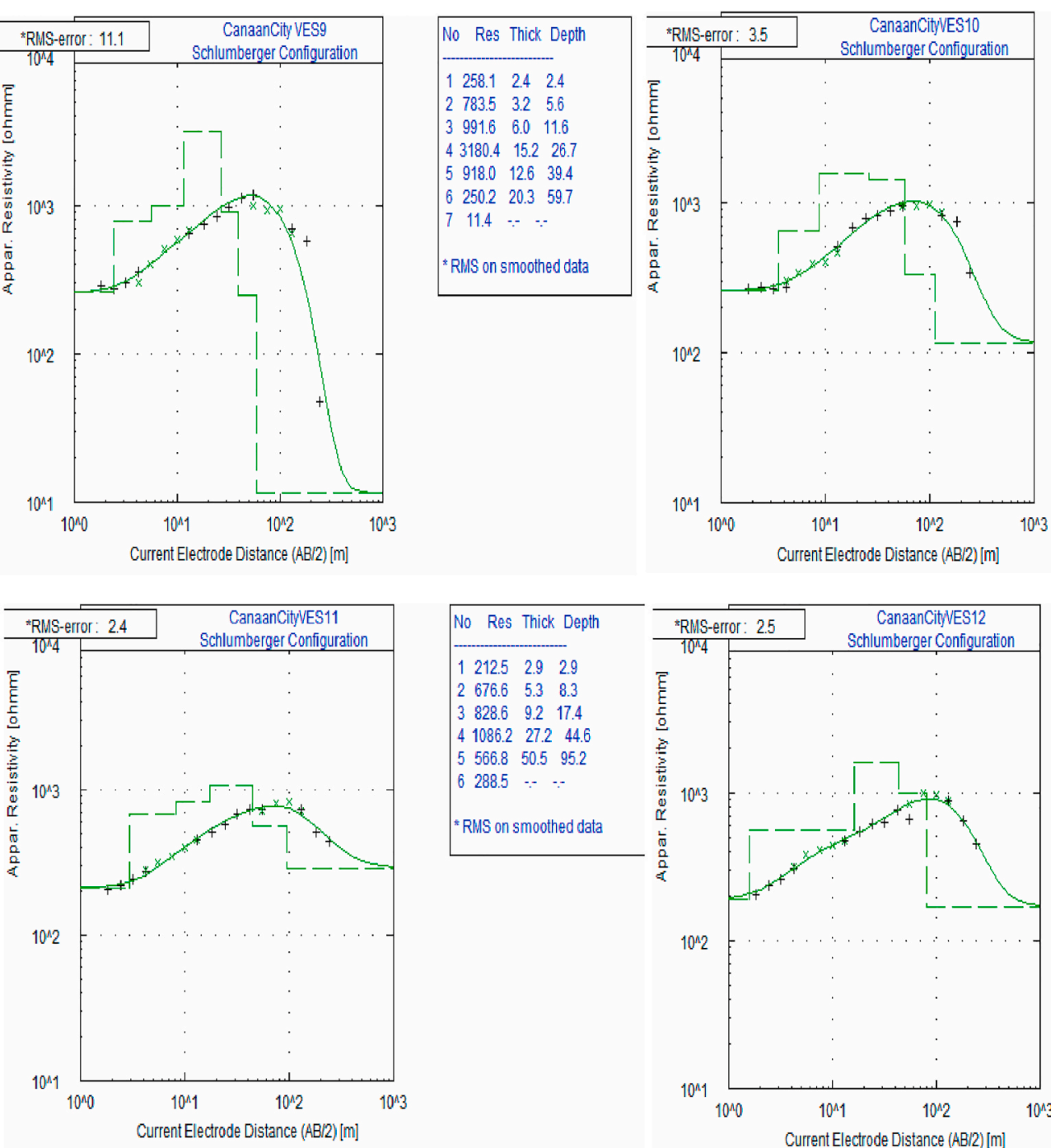
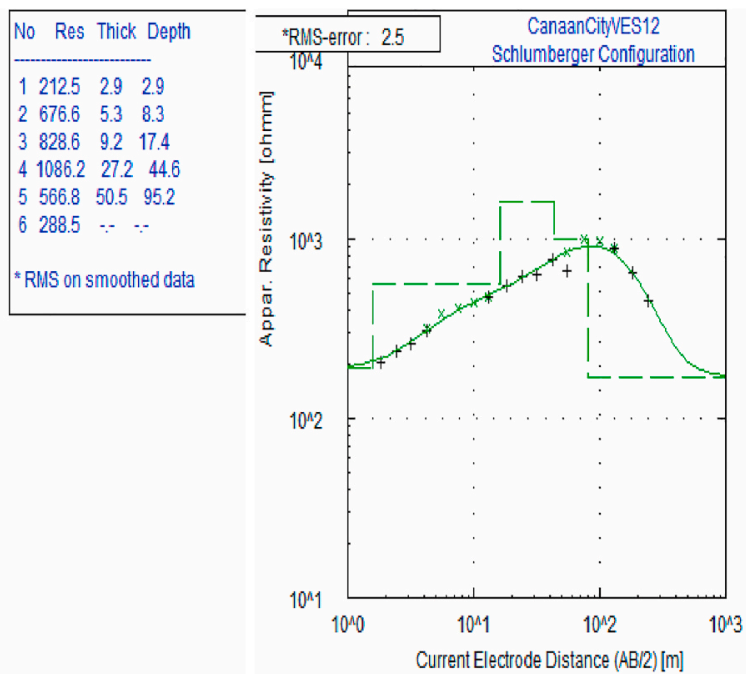

Fig. 5. Representative inverse resistivity models of VES 8-12. 
Table 2

Summary of layers parameters.

\begin{tabular}{|c|c|c|c|c|c|c|c|c|c|}
\hline \multirow[t]{2}{*}{ VES } & \multirow{2}{*}{$\begin{array}{l}\text { Curve } \\
\text { Type }\end{array}$} & \multirow[t]{2}{*}{ Lithology } & \multirow{2}{*}{$\frac{\text { Layer } 1}{\text { Top Soil }}$} & \multirow{2}{*}{$\frac{\text { Layer } 2}{\text { Sandy Clay }}$} & \multirow{2}{*}{$\frac{\text { Layer } 3}{\text { Lateritic Clay }}$} & \multirow{2}{*}{ Layer 4} & \multirow{2}{*}{$\frac{\text { Layer } 5}{\text { Clayey Sand (confining bed) }}$} & \multirow{2}{*}{$\frac{\text { Layer } 6}{\text { Sand (main aquifer) }}$} & \multirow{2}{*}{$\frac{\text { Layer } 7}{\text { Shale/Clay }}$} \\
\hline & & & & & & & & & \\
\hline \multirow[t]{3}{*}{1} & AAKQ & Resistivity & 272.7 & 538.5 & 845.7 & 1855.0 & 1339.5 & 530.8 & \\
\hline & & Thickness & 1.7 & 2.2 & 4.7 & 8.6 & 18.9 & & \\
\hline & & Depth & 1.7 & 3.9 & 8.6 & 17.2 & 36.1 & & \\
\hline \multirow[t]{3}{*}{2} & AAAK & Resistivity & 243.5 & 415.3 & 599.0 & 739.6 & 785.5 & 368.3 & \\
\hline & & Thickness & 1.8 & 2.8 & 5.6 & 9.9 & 24.7 & & \\
\hline & & Depth & 1.8 & 4.6 & 10.2 & 20.1 & 44.7 & & \\
\hline \multirow[t]{3}{*}{3} & AKQQ & Resistivity & 478.7 & 540.4 & 604.7 & 324.8 & 263.5 & 180.4 & \\
\hline & & Thickness & 1.4 & 2.0 & 6.8 & 15.7 & 45.5 & & \\
\hline & & Depth & 1.4 & 3.4 & 10.3 & 26.0 & 71.4 & & \\
\hline \multirow[t]{3}{*}{4} & KQHK & Resistivity & 391.2 & 1116.9 & 632.5 & 248.8 & 333.2 & 151.1 & \\
\hline & & Thickness & 1.6 & 1.5 & 9.2 & 11.0 & 59.8 & & \\
\hline & & Depth & 1.6 & 3.1 & 12.4 & 23.3 & 83.2 & & \\
\hline \multirow[t]{3}{*}{5} & KQHK & Resistivity & 320.5 & 614.6 & 236.6 & 171.2 & 259.7 & 81.9 & \\
\hline & & Thickness & 1.5 & 10.5 & 53.9 & 39.2 & 18.4 & & \\
\hline & & Depth & 1.5 & 12.0 & 65.9 & 105.1 & 123.5 & & \\
\hline \multirow[t]{3}{*}{6} & HAAK & Resistivity & 664.7 & 473.2 & 1058.0 & 1703.1 & 4941.7 & 734.7 & \\
\hline & & Thickness & 2.0 & 12.6 & 10.9 & 10.1 & 38.8 & & \\
\hline & & Depth & 2.0 & 12.6 & 25.6 & 35.6 & 74.4 & & \\
\hline \multirow[t]{3}{*}{7} & AAAK & Resistivity & 466.8 & 478.7 & 674.3 & 977.0 & 5139.9 & 542.5 & \\
\hline & & Thickness & 2.1 & 7.7 & 6.0 & 7.6 & 78.4 & & \\
\hline & & Depth & 2.1 & 9.8 & 15.8 & 23.4 & 101.8 & & \\
\hline \multirow[t]{3}{*}{8} & AKQQ & Resistivity & 27.0 & 296.3 & 3155.0 & 1280.4 & 853.1 & 287.8 & \\
\hline & & Thickness & 0.7 & 1.0 & 10.7 & 13.1 & 30.5 & & \\
\hline & & Depth & 0.7 & 1.7 & 12.4 & 25.5 & 56.0 & & \\
\hline \multirow[t]{3}{*}{9} & AAKQQ & Resistivity & 258.1 & 783.5 & 991.6 & 3180.4 & 918.0 & 250.3 & 11.4 \\
\hline & & Thickness & 2.4 & 3.2 & 6.0 & 15.2 & 12.6 & 20.3 & \\
\hline & & Depth & 2.4 & 5.6 & 11.6 & 26.7 & 39.4 & 59.7 & \\
\hline \multirow[t]{3}{*}{10} & AKQQ & Resistivity & 250.6 & 652.3 & 1591.9 & 1445.8 & 331.9 & 115.1 & \\
\hline & & Thickness & 3.6 & 5.1 & 17.5 & 31.1 & 55.2 & & \\
\hline & & Depth & 3.6 & 8.7 & 26.2 & 57.2 & 112.4 & & \\
\hline \multirow[t]{3}{*}{11} & AAKQ & Resistivity & 212.5 & 676.6 & 828.6 & 1086.2 & 566.8 & 288.5 & \\
\hline & & Thickness & 2.9 & 5.3 & 9.2 & 27.2 & 50.5 & & \\
\hline & & Depth & 2.9 & 8.3 & 17.4 & 44.6 & 95.6 & & \\
\hline \multirow[t]{3}{*}{12} & AKQ & Resistivity & 189.8 & 563.5 & 1620.1 & 1005.1 & & 167.6 & \\
\hline & & Thickness & 1.6 & 14.6 & 26.7 & 38.2 & & & \\
\hline & & Depth & 1.6 & 16.2 & 42.9 & 81.2 & & & \\
\hline
\end{tabular}

model resistivity range of 296.3-783.5 $\Omega \mathrm{m}$ and the thickness range of 1.0-14.6 $\mathrm{m}$. The third and fourth delineated layers are interpreted to be lateritic clay with resistivity range 991.6-3180.4 $\Omega \mathrm{m}$ and thickness up to $38.2 \mathrm{~m}$. The fifth layer is the confining bed, which is also a clayey sand layer with a resistivity range of 331.9-918.0 $\Omega \mathrm{m}$ and thickness range $12.6-55.2 \mathrm{~m}$. The sixth layer is interpreted to be the main aquifer unit, which is a coarse sand layer; the resistivity value range 115.1-288.5 $\Omega \mathrm{m}$. The seventh layer is interpreted to be a shale layer of Akinbo Formation with resistivity values of $11.4 \Omega \mathrm{m}$. The average depth to the top of the main aquifer within this part of the Canaan City is between $40 \mathrm{~m}$ and $112.4 \mathrm{~m}$.

The summary of the geoelectrical layers from VES are shown in Table 2 and geoelectrical cross-sections of both Location A and B are presented in Figs. 6 and 7. The cross-sections revealed the irregular nature of the depth to the top of the aquifer in the area. The crosssections also show that boreholes drill at different points in the area will encounter the main aquifer at different depths in the subsurface. A structural fault caused by a gentle displacement of subsurface layers is interpreted between VES 5 and VES 6. This fault may affect the productivity of the aquifer across the divide due to the variation in permeability of the aquifer unit caused by the displacement. Figs. 8 and 9 presented the aquifer's isoresistivity map and depth map of the study area, respectively. These maps are essential in the exploration, development, and management of the groundwater in the area. The isoresistivity map of the aquifer shows the resistivity variations from $\leq 100$ $\Omega m$ to $520 \Omega m$ in location A and $\leq 120 \Omega m$ to $280 \Omega m$ in location B. The map showing the distribution of the depths to the aquifer in the area reveals that the aquifer depth decreases towards the northern portion of location A and Southeastern part of location B. Estimation of porosity from the electrical resistivity data becomes quite imperative to determine the capacity of the aquifer system to hold and store water. The estimated aquifer porosity from the soundings data ranges between $\leq 28 \%$ and $\geq 74 \%$ in location $A$, while the data ranges between $\leq 37 \%$ and $\geq 61 \%$ in location B (Fig. 10). The map showing the distribution of the estimated porosity of the aquifer system in the area reveals that aquifer is highly porous. The porosity values in the area could be classified into high "A" $(\leq 28-44 \%)$, moderately high "B" (45-53\%), and very high " $C$ " (54- $\geq 74 \%)$; indicating that the highly porous coastal plain sands mixed with alluvium sand units of Benin Formation constitute the main aquifer system in the area.

\section{Conclusion}

Cost-effective geophysical investigations are commonly recommended before borehole drilling for groundwater resources, which is quite expensive and could be less productive or unproductive when not properly cited. Geoelectrical soundings were conducted in the new Canaan-City residential estate of Canaan land Ota, Ogun state. The study was carried out to avoid drilling unproductive borehole and low yield borehole in the area. The results revealed subsurface stratigraphy with geoelectrical units, including the topsoil (clay), sandy clay, lateritic clay, confining bed (clay) and the main aquifer (sand). The shale unit belonging to the Akinbo Formation was delineated in some parts of the study area. Also, a structural fault is interpreted between VES 5 and VES 6. This fault occurrence within the subsurface in this part of the study area may result in the variation of permeability across the divide, thereby affecting the productivity of the aquifer unit. The depth to the top of the main aquifer is in the range of $40-112.4 \mathrm{~m}$ and the estimated porosity range from $28 \%$ to $74 \%$ revealing that the high porosity aquifer system in the area is that of the coastal plain sands mixed with the 

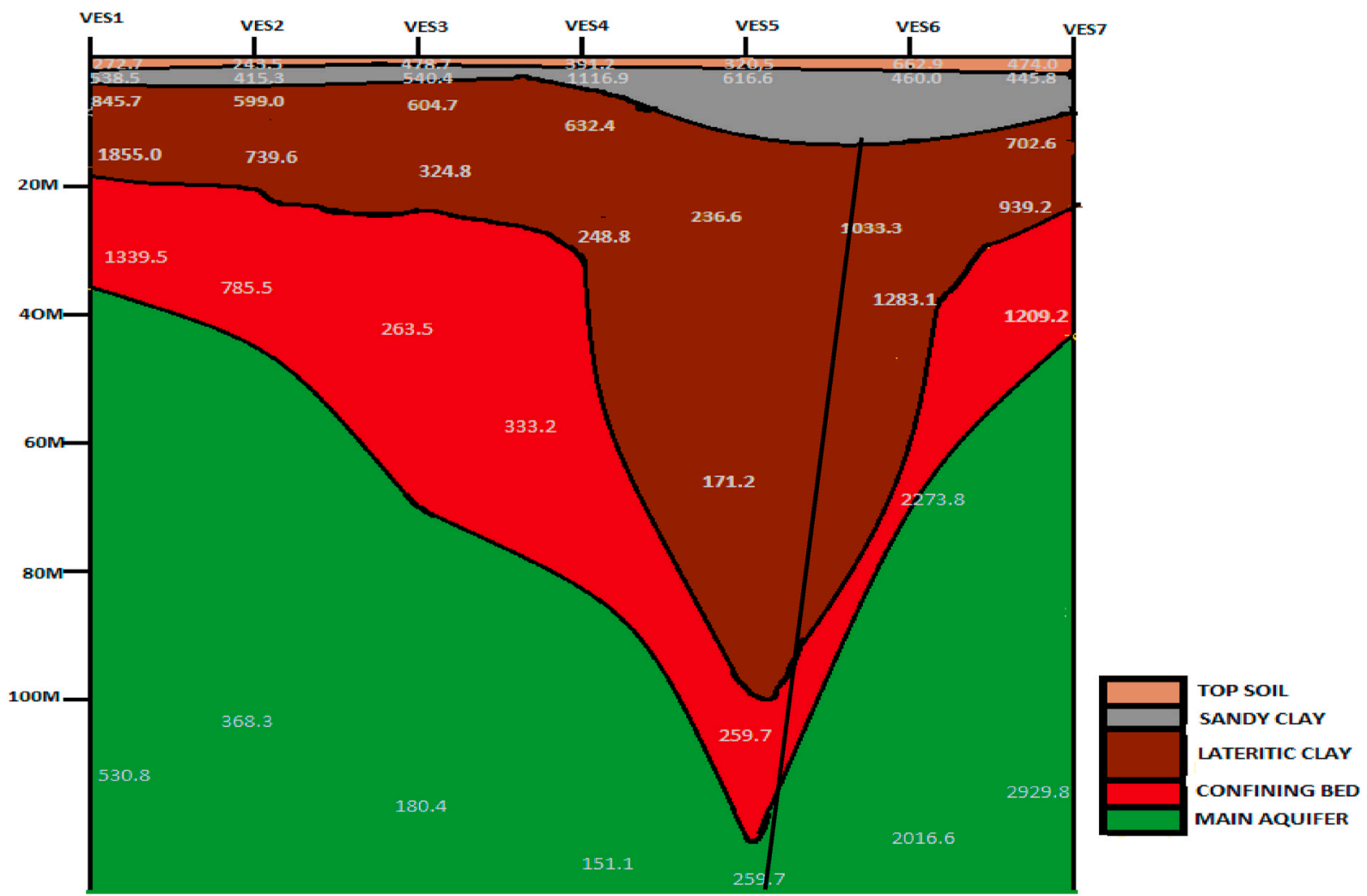

Fig. 6. Geoelectrical section through VES1-7.
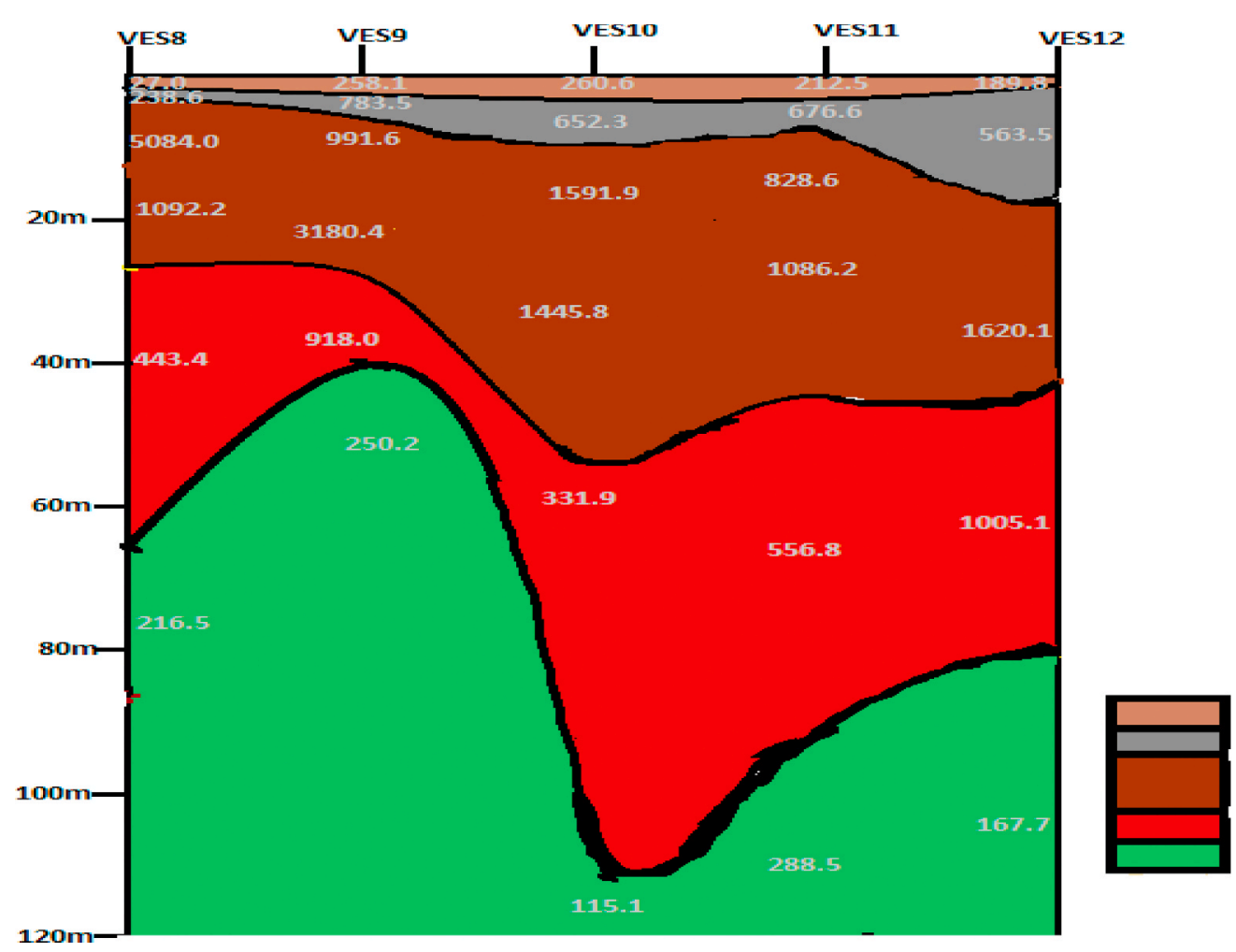

TOP SOIL

SANDY CLAY

LATERITIC CLAY

LATERITIC CLAY

CONFINING BED

MAIN AQUIFER

Fig. 7. Geoelectrical section through VES 8-12. 


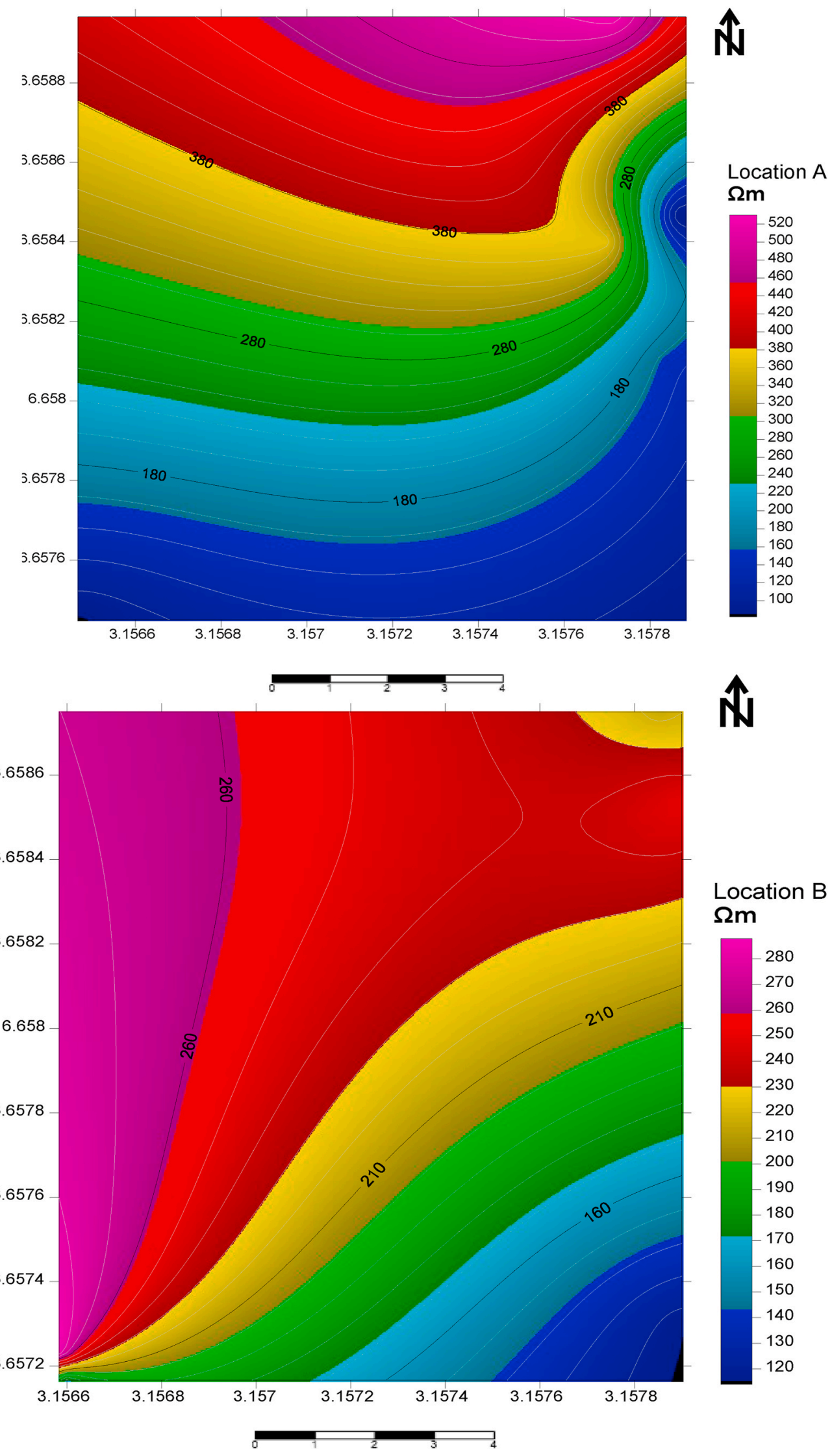

Fig. 8. The Isoresistivity of the aquifer system at locations A and B. 

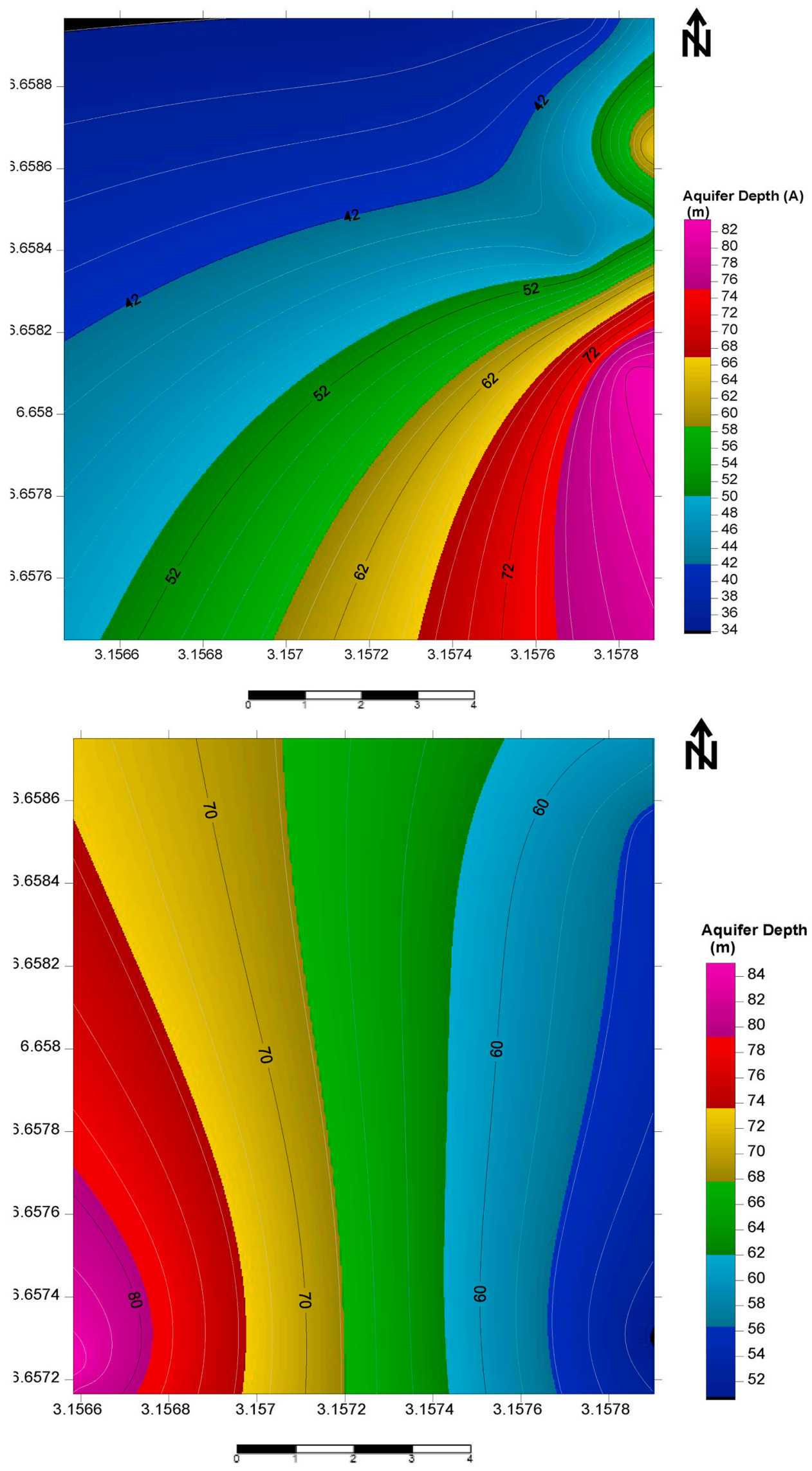

$\hat{N}$

Fig. 9. Map of the aquifer's depths at locations A and B.

Aquifer Depth (B)

(m)

$-84$

$-82$

$-80$

$-78$

-76
-74

$-72$

70

-68
-66

$-64$

-62
-60

58
56

56
-54

$-52$ 


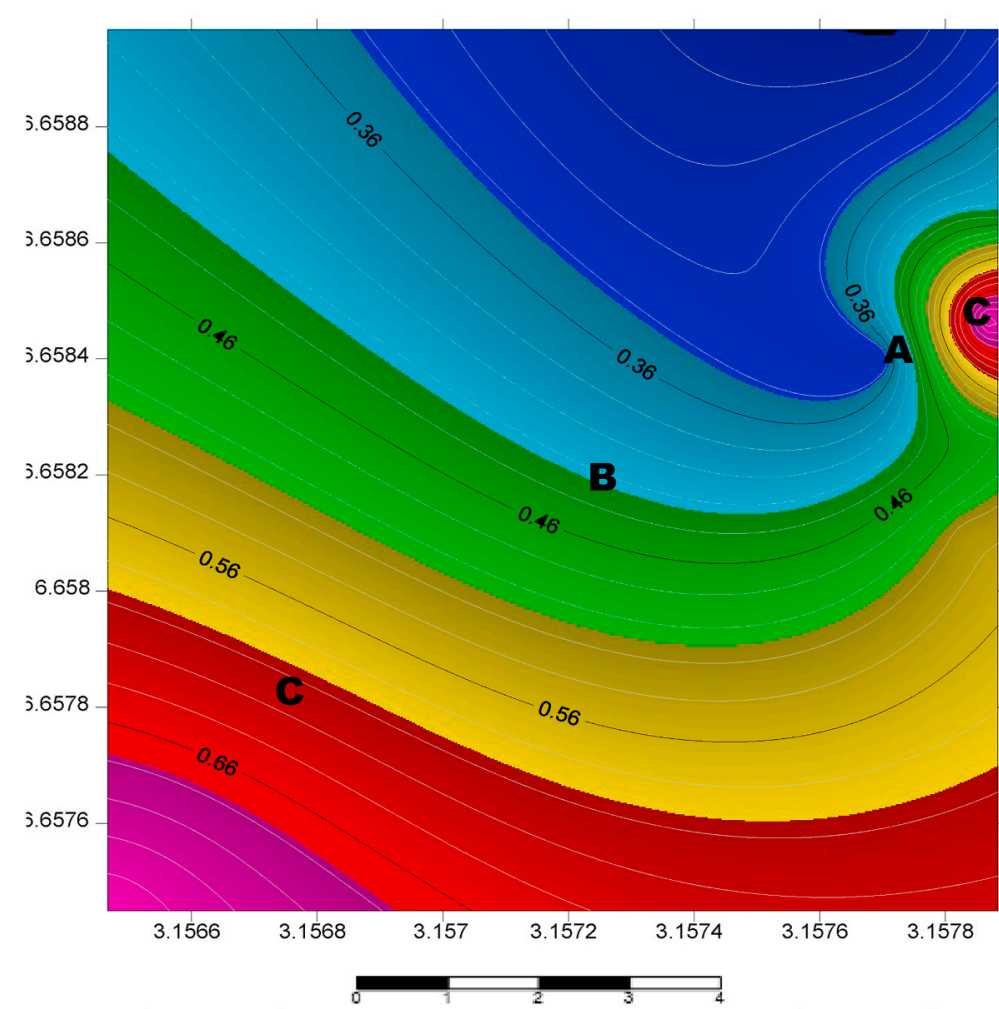

N

Aquifer Porosity (A) (Fraction)
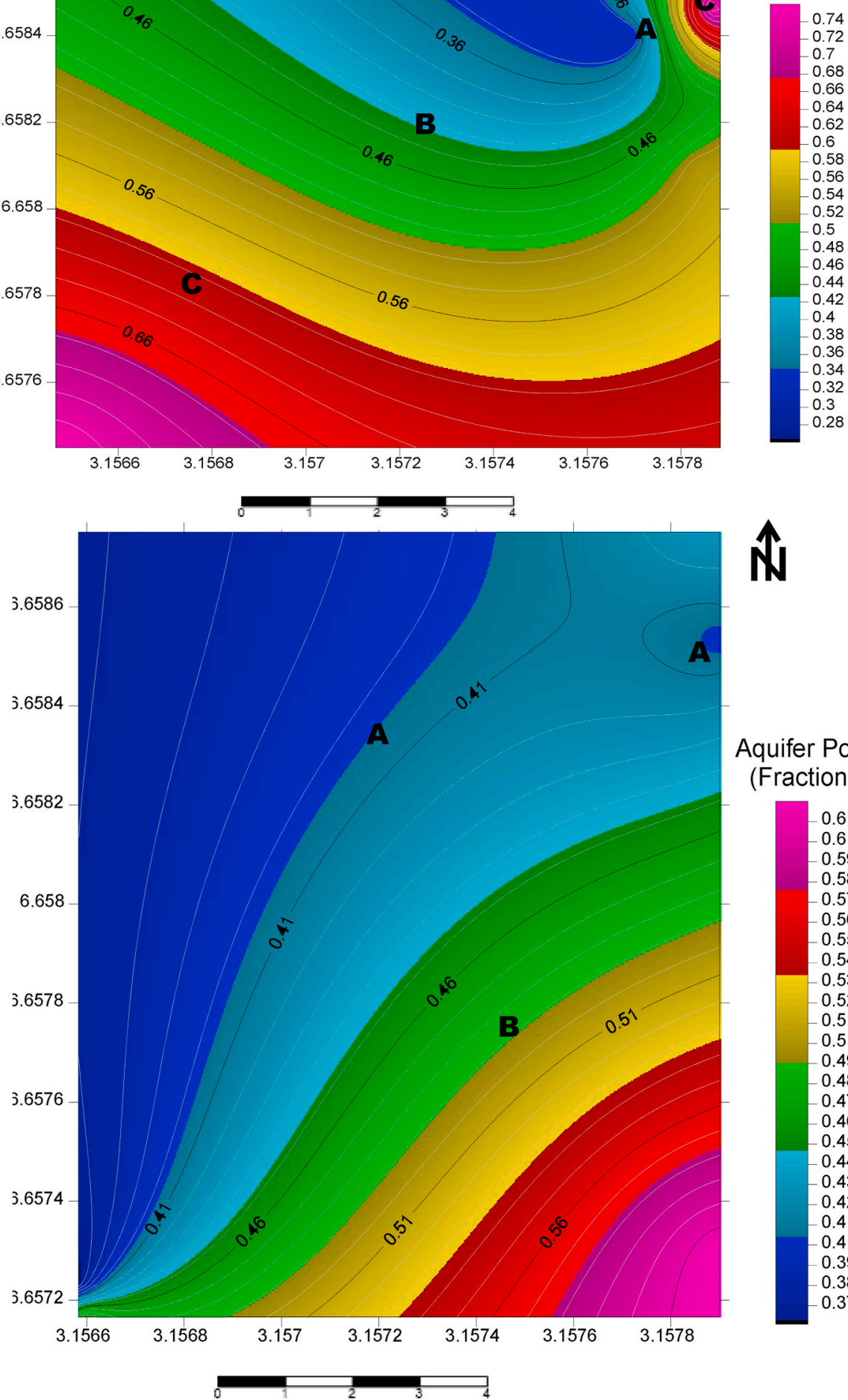

$\hat{\mathbb{N}}$

Aquifer Porosity (B) (Fraction)

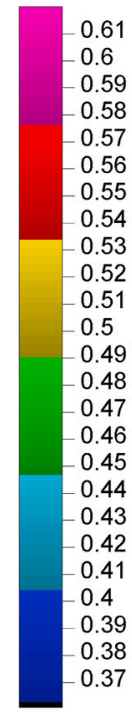

Fig. 10. Map of the aquifer porosity at locations A and B. 
alluvium sand of the Benin Formation of Dahomey Basin. The delineated main aquifer architecture is generally complex with undulating topography, thus targeting this aquifer may be difficult at some points. Pumping test is recommended to be able to estimate other geo-hydraulic parameters and generate a 3D model of the aquifer system in the area.

\section{Declaration of competing interest}

The authors declare that they have no known competing financial interests or personal relationships that could have appeared to influence the work reported in this paper.

\section{Acknowledgment}

The authors extend their appreciation to the Deanship of Scientific Research at King Saud University for funding this work through research group No (RG-1440-036). Also, we thank the Covenant University Centre for Research Innovation and Development (CUCRID) for their support.

\section{References}

Aizebeokhai, A.P., Oyeyemi, K.D., 2015. Application of geoelectrical resistivity imaging and VLF-EM for subsurface characterization in a sedimentary terrain, southwestern Nigeria. Arab. J. Geosci. (Springer) 8 (6), 4083-4099.

Aizebeokhai, A.P., Oyeyemi, K.D., Joel, E.S., 2016a. Electrical Resistivity and Induced Polarization Imaging for Groundwater Exploration. SEG Technical Program Extended Abstracts, pp. 2487-2491.

Aizebeokhai, A.P., Oyeyemi, K.D., Joel, E.S., 2016b. Groundwater potential assessmen in a sedimenatry terrain, southwestern Nigeria. Arab. J. Geosci. (Springer) 9, 496. https://doi.org/10.1007/s125-016-2524-5.

Aizebeokhai, A.P., Ogungbade, O., Oyeyemi, K.D., 2017a. Integrating VES and 2D ERI for Near-Surface Characterization in a Crystalline Basement Terrain. SEG Technical Program Extended Abstracts, pp. 5401-5406.

Aizebeokhai, A.P., Oyeyemi, K.D., Noiki, F.R., Etete, B.I., Arere, A.U.E., Eyo, U.J., Ogbuehi, C, V., 2017b. Geoelectrical resistivity data sets for characterization and aquifer delineation in Iyesi, southwestern Nigeria. Data Brief 15, 828-832. https:// doi:10.1016/j.dib.2017.10.057.

Aizebeokhai, A.P., Oyeyemi, K.D., 2018. Geoelectrical characterization of basement aquifers: the case of Iberekodo southwestern Nigeria. Hydrogeol. J. 26 (2), 651-664.

Aizebeokhai, A.P., Oyeyemi, K.D., 2018b. Geoelectrical Resistivity Surveying for Aquife Delineation and Characterization in a Sedimentary Terrain, Southwestern Nigeria. SEG Technical Program Expanded Abstracts, pp. 4899-4903.

Aizebeokhai, A.P., Ogungbade, O., Oyeyemi, K.D., 2018a. Geoelectrical resistivity dataset for characterizing crystalline basement aquifers in Basiri, Ado-Ekiti, Southwestern Nigeria. Data Brief (Elsevier) 19, 810-816.

Aizebeokhai, A.P., Oni, A.A., Oyeyemi, K.D., Ogungbade, O., 2018b. Electrical resistivity imaging (ERI) data for characterising crystalline basement structures in Abeokuta, southwestern Nigeria. Data Brief (Elsevier) 19, 2393-2397. https://doi:10.1016/j. dib.2018.07.034.

Aizebeokhai, A.P., Oyeyemi, K.D., Adebola, E.A., 2019. 2D ERI for groundwater in a crystalline Basement terrain, Abeokuta, Southwestern Nigeria. In: Chamine, H.I., et al. (Eds.), Advances in Sustainale and Enviromental Hydrology, Hydrogeology, Hydrochemistry and Water Resources, Advances in Science, Technology and Innovation. Springer. https://doi:10.1007/978-3-01572-558.

Ako, B.D., Adegoke, O.S., Petters, S.W., 1980. Stratigraphy of oshoshun Formation in southwestern Nigeria. Nig. J. Mining Geol. 17, 99-106.

Balkaya, Ç., Kaya, M.A., Göktürkler, G., 2009. Delineation of shallow resistivity structure in the city of Burdur, SW Turkey by vertical electrical sounding measurements. Environ. Geol. 57, 571-581. https://doi.org/10.1007/s00254-008-1326-9.

Chandra, S., Ahmed, S., Ram, A., Dewandel, B., 2008. Estimation of hard rock aquifers hydraulic conductivity from geoelectrical measurements: a theoretical Development with filled application. J. Hydrol. 357, 218-277.
Elueze, A.A., Nton, M.E., 2004. Organic geochemical appraisal of limestones and shales in part of eastern Dahomey basin, southwestern Nigeria. J. Min. Geol. 40 (1), 29-40.

Fatoba, J.O., Sanuade, O.A., Hammed, O.S., Igboama, W.W., 2017. The use of multivariate statistical analysis in the assessment of groundwater hydrochemistry in some parts of southwestern Nigeria. Arab. J. Geosci. 10, 328. https://doi.org/ 10.1007/s12517-017-3125-7.

Gebhardt, H., Adekeye, O.A., Akande, S.O., 2010. Late Paleocene to initial Eocene thermal maximum foraminifera biostratigraphy and paleoecology of the Dahomey basin, southwestern Nigeria. Gjahrbuch Der Geologischem. Bundesantalt 150, 407-419.

Jones, H.A., Hockey, R.D., 1964. The geology of part of south western Nigeria. Geol. Surv. Nigeria Bull. 31, 1-101.

Karlık, G., Kaya, M., 2001. Investigation of groundwater contamination using electric and electromagnetic methods at an open waste-disposal site: a case study from Isparta, Turkey. Environ. Geol. 40, 725-731. https://doi.org/10.1007/ s002540000232.

Kaya, M.A., Özürlan, G., Şengül, E., 2007. Delineation of soil and groundwater contamination using geophysical methods at a waste disposal site in çanakkale, Turkey. Environ. Monit. Assess. 135, 441-446. https://doi.org/10.1007/s10661 007-9662-x.

Keller, G.R., 1987. Rock and minerals properties. In: Nabighian, M.N. (Ed.), Electromagnetic Methods in Applied Geophysic-Theory. Society of Exploration Geophysics, pp. 13-52. https://doi/10.1190/1.9781560802631.ch2.

Meju, M.A., Fontes, S.L., Oliveira, M.F.B., Lima, J.P.R., Ulugergerli, E., et al., 1999. Regional aquifer mapping using combined VES-TEM-AMT/EMAP methods in the semiarid eastern margin of Parnaiba Basin, Brazil. Geophysics 64, 337-356.

Okosun, E.A., 1990. A review of the cretaceous stratigraphy of the Dahomey embayment, west Africa. Cretac. Res. 11, 17-27.

Olabode, S.O., 2006. Silclastics slope deposits from the cretacious Abeokuta group, Dahome (Benin) basin, southwestern Nigeria. J. Afr. Earth Sci. 46, 187-200.

Olaojo, A.A., Oladunjoye, M.A., Sanuade, O.A., 2018. Geoelectrical assessment of polluted zone by sewage effluent in University of Ibadan campus southwestern Nigeria. Environ. Monit. Assess. 190, 24. https://doi.org/10.1007/s10661-0176389-1.

Omatsola, M.E., Adegoke, O.S., 1981. Tectonic evolution and cretaceous stratigraphy of the Dahomey Basin. Nig. J. Mining Geol. 18, 130-137.

Oyeyemi, K.D., Olofinnade, O.M., 2016. Geoelectrical -Geotechnical studies for near surface characterization, case history: Lagos, SW Nigeria. Electron. J. Geotech. Eng. 21 (10), 3735-3750.

!"count(.//sb:host[1]//child::*//sb:date)" > Oyeyemi, K.D., Aizebeokhai, A.P., Olofinnade, O.M., Sanuade, O.A., . Geoelectrical investigations for groundwater exploration in crystalline basement terrain, SW Nigeria: implications for groundwater resources sustainability. Int. J. Civ. Eng. Technol. 9 (6), 765-772.

Oyeyemi, K.D., Aizebeokhai, A.P., Ndambuki, J.M., Sanuade, O.A., Olofinnade, O.M. Adagunodo, T.A., Olaojo, A.A., Adeyemi, G.A., 2018b. Estimation of aquifer parameters from surficial geophysical methods: a case study of Ota, Southwestern Nigeria. IOP Conf. Ser. Earth Environ. Sci. 173 (1), 012028.

Oyeyemi, K.D., Aizebeokhai, A.P., Sanuade, O.A., Ndambuki, J.M., Olofinnade, O.M., Adagunodo, T.A., Olaojo, A.A., 2018c. The use of geological-based geophysical surveys for groundwater distribution in crystalline basement terrain, SW Nigeria. IOP Conf. Ser. Earth Environ. Sci. 173 (1), 012029.

Oyeyemi, K.D., Aizebeokhai, A.P., Sanuade, O.A., 2019. Geological-geophysical investigations for hydrological studies in a basement complex terrain, southwestern Nigeria. In: Chamine, H.I., et al. (Eds.), Advances in Sustainale and Enviromental Hydrology, Hydrogeology, Hydrochemistry and Water Resources, Advances in Science, Technology and Innovation. Springer. https://doi:10.1007/978-3-0 1572-5_58.

Soupios, P.M., Kouli, M., Valianatos, F., Vafidis, A., Stavroulakis, G., 2007. Estimation of aquifer hydraulic parameters from surficial geophysical methods: a case study of Keritis basin in Chania (Crete-Greece). J. Hydrol. 338, 122-131.

Umi Maslinda, A., Nordiana, M.M., 2018. Aquifer Detection using 2-D resistivity method and prorosity calculation. J. Teknologi 80 (6), 149-158.

Uyanı, O., 2011. The porosity of saturated shallow sediments from seismic compressional and shear wave velocities. J. Appl. Geophys. 73 (1), 16-24. https:// doi.org/10.1016/j.jappgeo.2010.11.001.

Yadav, G.S., 1995. Relating hydraulic and geoelectric parameters of the Jayant Aquifer, India. J. Hydrol. 167, 23-38. 